\title{
Editorial: Current Trends in Postgraduate Research in the Social Sciences
}

\author{
Kalpana Hiralal \\ Sultan Khan
}

Post graduate research is basically a formal study that is carried out by a candidate at a tertiary institution. It is an extension of study from the undergraduate level. In essence, it may be dubbed as serving an 'apprenticeship' in a particular field in which a systematic investigation is conducted based on the work of peers that extends the present state of knowledge. Master's and Doctorate degrees are common postgraduate programmes in which students engage in independent research. Research at a postgraduate level need not necessarily result in a major breakthrough. It can be an extension of knowledge or add to an existing body of knowledge.

Postgraduate research programmes varies globally. In developed countries, the availability of funds and research resources helps to promote a large cohort of postgraduate students. In developing and under-developed countries, one finds that postgraduate study opportunities are limited resulting in a knock on effect on the availability of scarce skills for these nation states. Developing and under-developed countries are denied an opportunity to produce a strong cohort of postgraduate candidates in diversified fields of study which indirectly leads to 'brain drain'. Often in these countries one finds that postgraduate students migrate to developed countries on scholarship programmes to pursue their study. Some return to their home country to serve it, while others remain in the country of sponsorship or migrate to another country in search of jobs. Postgraduate students from developing and underdeveloped countries on completion of their studies abroad are often despondent to return to their home countries with the anxiety that they will not get the rewards for their educational qualification, or there might be no opportunity to find secure employment. 
No matter where postgraduate students study they are expected to complete research projects as a requirement to obtain their academic qualifications. These research projects are resource intensive which demands large amounts of monies to be invested in them, requiring long hours of supervision and is time intensive. It is anticipated that on completion of the research projects it will create, inform knowledge or influence policy. If these objectives are not met, then it will be tantamount to wasting resources as the ordinary taxpayer does not benefit from it (Obuku et al. 2017a). Ideally, it is expected that postgraduate research should find itself in the public domain so that it can make a contribution to society. In order to find itself in the public domain it needs to be published either as academic papers, book chapters, technical reports or opinion pieces in the public media. Although this may be the ideal, in practice it is far from reality. Obuku et al. (2017b) observe in their study in Uganda found that the productivity and use of post graduate students research at Makerere University is considerably low in terms of peer-reviewed publications and citations in policy related documents. They located 1172 dissertations of Masters students over a 20 year period (1996-2010) and found that only $4 \%$ of policy related documents cited these dissertations. Obuku et al. (2017b) conclude that investing in research that is not accessible or used is a waste of resources and an injustice to human subject participants, collaborators, funders and the scientific community at large.

The nature and category of topics in postgraduate research are varied and diverse. Discipline specific are opening new pathways to topic and methodologies. For example, in history, in South Africa, there is a strong emphasis on revisionist history. Moreover, oral histories have become a valuable tool to unearth lost histories and marginalized voices. One of the key themes permeating in this collection is that of migration.

Migration of peoples and communities has occurred since time immemorial. In the contemporary period, globalization has led to the migration of peoples, ideas, goods and commodities. It has also had serious implications on peoples identity and citizenship in the migration process. Arjun Appadurai (1996) a socio-cultural anthropologist, alludes to the impact of global communications flows - electronic mass media and communication technologies- which has led to the fluidity, heterogeneity and mobility of communities, cultures and localities (Appadurai 1996:60). Other scholars such as Jacqui Alexander and Chandra Mohanty (1997) have highlighted the need to re-visit and reconceptualise terms such as 'immigrants', 'refugees', 'guest- 
workers', and 'citizens' (1997: xix) in varying geo-political contexts, time and space. Migrants have plural and not singular identities and hence should not be zoned into compartments (Curti 2009; Govinden 2014:6-12).

Migration both internal from a country's borders (rural to urban) and across national borders has undoubtedly created challenges for both immigrants and the inhabitants of the host country. It has raised issues of identity, borders, nation and state. These concepts have been problematized and deliberated by scholars such as Anzaldua (1999) and Butler and Spivak (2007). Anzaldua (1999) in Borderlands/ La Frontera: The New Mestiza (1999) problematizes the notion of borders as follows:

The US - Mexican border es una herida abierta [is an open wound] where the Third World grates against the first and bleeds. And before the scab forms it haemorrhages again, the lifeblood of two worlds merging to form a third country - a border culture. Borders are set up to define the places that are safe and unsafe, to distinguish us from them. A border is a dividing line, a narrow strip along a steep edge. A borderland is a vague and undetermined place created by the emotional residue of an unnatural boundary. It is in a constant state of transition. The prohibited and forbidden are its inhabitants (Anzaldua 1999:24; cited in Govinden 2014).

She alludes to the psychological, physical and socio-economic challenges of immigrant life,

The world is not a safe place to live in. We shiver in separate cells in enclosed cities, shoulders hunched, barely keeping the panic below the surface of the skin, daily drinking shock along with our morning coffee, fearing the torches being set to our buildings, the attacks in the streets... Alienated from her mother culture, 'alien' in the dominant culture, the woman of colour does not feel safe within the inner life of her Self (Anzaldua 1999:20; cited in Govinden 2014: 16).

Butler and Spivak (2007), in Who Sings the Nation-State? - Language, Politics, Belonging (2007), allude to the complexities of nation and state and argue that the state is a more provisional place and that the nation-states 
produce 'states of being', such as 'citizen', 'exile', 'refugee', or 'alien' (Govinden 2014: 6-12).

The idea of nation has had serious implications for both immigrants and peoples of the host country. It has drawn lines between those that are considered alien and those who are perceived as native or indigenous. In South Africa, the outbreak of xenophobic violence against immigrants from across Africa and elsewhere has forced open debates on notions of citizenship, foreign, alien and nation-building. However, these challenges are not confined to South Africa only. In Europe the current wave of migration across the various European countries has not only created anti-immigration sentiments but also created new political alignments (The Sunday Tribune $26^{\text {th }}$ October 2014). Anti-immigration sentiments have been countenanced by humanitarian voices seeking to provide a more humane solution to the current migration crisis. For example, in the United Kingdom, the Archbishop of Canterbury, Justin Welby, stated,

The language we use must reflect the value of the human being, and not treat immigration as just a deep menace that is somehow going to overwhelm a country that has coped with many waves of immigration successfully (The Mercury $28^{\text {th }}$ October 2014).

The collection of articles in this volume reflects the complexities of migration as alluded in the above discussion. It showcases the diverse and varies topics of students across universities in South Africa dealing with migration and diaspora in the context of identity, politics, displacement and sexuality. The topics are not only popular but significant given the socio-economic and political challenges that currently exist in South Africa. These topics will certainly contribute to new perspectives and understanding to some of the problems facing South Africa and beyond. It is against this backdrop, that this volume of Alternation showcases the work of five post graduate students in the humanities and social sciences. All five papers focuses on the theme of migration in the context of identity, politics and history.

In the paper titled 'The implications of forced relocation on perceptions of identity and belonging in the Post Apartheid State', Karthigasen Gopalan provides a snapshot of forced removal, relocation and resettlement during the apartheid era. He makes reference to the Group Areas Act (1950) which was a notorious piece of legislation that aimed to separate races from 
mixing by relocating settled communities into local residential areas known as townships. His paper looks at the minority immigrant Indian community in the city of Durban and how they have been victims of the Group Areas Act. In particular he looks at the settled community in the neighbourhood of Durban known as Magazine Barracks and how they have been uprooted and resettled in the all Indian township of Chatsworth, South of Durban. He reconstructs how residents despite their poor and crowded living conditions in Magazine Barracks took advantage to create a sense of community through religious and cultural institutions and produced a rich sporting and academic heritage. After sixty years of resettlement, the residents of Magazine Barracks now living in the township of Chatsworth continue to reflect in their identity their past history.

Divane Nzima's article examines the role of remittances in shaping and defining immigrants lives. This study focuses on Zimbabwean migrants residing in South Africa who remit monies to the Tsholotsho District in Zimbabwe and some of the challenges and constraints they endure in the process. Her findings correlates with national and international studies that highlight that for many immigrants the preferred mode of remittances is through informal channels as opposed to the formal ones. This article not only provides insights into the complexity of remittances in the migration process, but the overall impact it has in family households and the economy in the home country.

Shabnam Shaik in her article 'HIV/AIDS and Muslims in South Africa: The "Untouchable" Disease' examines a very pertinent and significant topic in the context of religion, identity and culture in the migration process. The study is exploratory in nature, and seeks to examine and explore the social and cultural challenges that Muslims with HIV/AIDS experience. Shaik utilizes life histories, to extract personal experiences and to highlight how Muslims living with the disease negotiate and accommodate their status in the context of religious and social ostracism and myths relating to the disease. This study is valuable as it provides deep insights into how religion and ethnicity shape and define identity in the context of HIV/AIDS.

Yamkela Majikijela and Gabriel Tati's article examines the structural changes in the participation of African migrants in the labour force of South Africa from 2001 to 2011. It locates the discussion in the context of the deployments of African immigrants in terms of occupation, employment sector and income groups. The authors conclude that male migrants still constitute a 
higher proportion of the labour force compared to women. This gender inequity was most noticeable in the context of education, employment and labour.

Collectively the articles in this special edition provide some insights to the trends and patterns of postgraduate research in South Africa. A critical analysis of current postgraduate studies is essential, not only to increase postgraduate throughputs but also to promote engaging research which will be beneficial to the wider South African public.

\section{Reference}

Alexander, J.M. \& C.T. Mohanty (eds.) 1997. Feminist Genealogies, Colonial Legacies, Democratic Futures. Routledge: New York, London.

Anzaldua, G. 1999. Borderlands/ La Frontera: The New Mestiza. San Francisco: Spinsters/ Aunt Lute.

Appadurai, A. 1996. Modernity at Large - Cultural Dimensions of Globalisation. Minneapolis: University of Minnesota Press.

Butler, J. \& G.C. Spivak 2007. Who Sings the Nation-state? Language, Politics, Belonging. London:: Seagull Books.

Curti, L. 2009. Transcultural Itineraries in Women's Literature of Migration in Italy. Paper presented as part of conference to celebrate the $30^{\text {th }}$ anniversary of Feminist Review. SOAS, University of $26^{\text {th }}$ London September 2009.

Govinden, B. 2014. Seasons of Migration - Reflections and Possibilities in the Study of Women and Migration-Borders, Bodies and Boundaries: Removing the Barbed Wire and High Fences. Unpublished paper presented at Borders, Bodies and Boundaries Workshop, University of Witwatersrand, Johannesburg, pp. 1-43.

Obuku, E.A., J.N. Lavis, A. Kinengyere, D.K. Mafigiri, F. Sengooba, C. Karamagi \& N.K. Sewankambo 2017a. Where is Students' Research in Evidence-Informed Decision-Making in Health? Assessing Productivity and Use of Postgraduate Students' Research in Low- and Middle-Income Countries: A Systematic Review. Health Research Policy and Systems 15,1,18: 2-7. doi: 10.1186/s12961-017-0169-9.

Obuku, E.A., J.N. Leavis, A. Kinengyere \& N. Sewankambo 2017b. Academic Research Productivity of Post-graduate Students at Makerere University College of Health Sciences, Uganda, from 1996 to 2010: A Retrospective 
Review. Health Research Policy Systems 5,30: 2-10. Available at https://www.researchgate.net/publication/315960772. (Accessed on 9 August 2017.)

The Mercury 2014. Anti-immigration Tone a Worry. $28^{\text {th }}$ October 2014.

The Sunday Tribune 2014. Desperate Migrants Seeking a Haven. 26 ${ }^{\text {th }}$ October 2014.

Kalpana Hiralal Department of History University of KwaZulu-Natal hiralalk@ukzn.ac.za

Sultan Khan Department of Sociology University of KwaZulu-Natal khans@ukzn.ac.za 